\title{
Troilite (FeS) Oxidation in the Presence of a Newly Synthesized TRIS-based Base
}

\author{
MADALINA IONELA DUINEA ${ }^{1,2}$, GETA CARAC ${ }^{1}$, IRINA DANIELA DABULEANU2,*, MIHAELA ALEXANDRA PETCU ${ }^{2}$, \\ LAURA GABRIELA SARBU ${ }^{3}$, MIHAIL LUCIAN BIRSA ${ }^{3}$, PAUL CHIRITA ${ }^{2}$ \\ 'Dunarea de J os University of Galati, Faculty of Sciences and Environment, 111 Domneasca Street, Galati, 800201, Romania \\ 2University of Craiova,Department of Chemistry, Calea Bucuresti 107l, Craiova, 200478, Romania \\ ${ }^{3} \mathrm{Al}$. I. Cuz" University of Iasi, Department of Chemistry, 11 Carol I Blv., Iasi, 700506, Romania
}

\begin{abstract}
The effect of a newly synthesized TRIS-based Schiff base (XC) on the oxidative dissolution of FeS in airequilibrated solutions with $\mathrm{pH} 2.26$ and temperature of $27^{\circ} \mathrm{C}$ was investigated by Potentiodynamic polarization, Cyclic Voltammetry, Optical Microscopy and quantum chemical calculations. The XC concentration varied between 0 and $0.52 \mathrm{mM}$. It was observed that $X C$ decreases the corrosion current densities of the oxidative dissolution of FeS. Our results indicate that the inhibitory effect of XC is due to its adsorption on the FeS surface.
\end{abstract}

Keywords: FeS oxidation, Inhibition, Potentyodynamic polarization, Cyclic Voltammetry, Quantum chemical calculations

Iron monosulfides (pyrrhotite, troilite and mackinawite) are among the most reactive mineral sulfides. Their formation occurs in anoxic media where sulfides are generated by the reaction of $\mathrm{Fe}(\mathrm{II})$ and S(-II) [1]. In contact with dissolved oxygen or ferric iron, the iron monosulfides are oxidized. The oxidation products have multiple implications for the environment [2-4]. On the one hand, the released protons and toxic species incorporated in their matrix produce the phenomenon of acid mine drainage, and, on the other hand, their surfaces control the mobility of some ions in aqueous media $[5,6]$.

By partial oxidation, the surface of the iron monosulfide is enriched in sulfur [ 7-12].

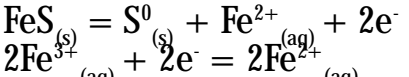

$$
\begin{aligned}
& 1 / 2 \mathrm{O}_{2(\mathrm{aq})}+2 \mathrm{H}^{+}{ }_{(\mathrm{aq})}+2 \mathrm{e}^{-\stackrel{(\mathrm{aq})}{=}} \mathrm{H}_{2} \mathrm{O}
\end{aligned}
$$

The product layer formed on the surface of the iron monosulfide contains elemental sulfur $\left(\mathrm{S}^{\circ}\right)$ and various polysulfide ions. At a $\mathrm{pH}>3$, Fe (III) precipitates and the FeS surface becomes rich in Fe(III) oxyhydroxides. Ferric iron (Fe(III)) is generated by the oxidation of ferrous iron (Fe(II)) with oxygen. In acidic environment, the resulted ferric iron is an effective oxidant. At higher $\mathrm{pH}$ values, its role is taken by dissolved oxygen [3]. We can assume that the presence of ferrous and/or ferric iron ligands in the reaction systems may change the balance between the activities of the oxidant species and implicitly may affect the rate of oxidative dissolution of $\mathrm{FeS}$. Ferrous iron ligands stabilizes Fe(II), which will slow its oxidation to Fe(III), but at the same time they can speed up the release of ferrous iron, generating the FeS destruction. Another way to control the rate of FeS oxidation is the use of organic inhibitors [2,13-15]. Data from the literature shows that most of the organic inhibitors act by adsorption on the surface of the mineral sulfides. Surface adsorption occurs through heteroatoms (nitrogen, oxygen, phosphorus, sulfur etc.), multiple bonds and aromatic cycles. The organic layer resulted by adsorption of the organic molecules acts as a barrier for the electron transfer to oxidant $[2,14]$.
The purpose of this study was to investigate the effect of a newly synthesized TRIS-based Schiff base (XC) on the oxidative dissolution of troilite (stoichiometric iron monosulfide, FeS) in acid solutions ( $\mathrm{pH} 2.26$ ) and at $27^{\circ} \mathrm{C}$ by electrochemical techniques (Potentiodynamic polarization and Cyclic Voltammetry). Because the oxidative dissolution of iron monosulfide is an electrochemical process [15], it can be successfully investigated by electrochemical techniques. The interaction between FeS and XC was analyzed by quantum chemical calculations.

\section{Experimental part \\ Materials \\ Troilite (FeS)}

Experiments were performed with synthetic iron monosulfide purchased from Merck. As was proven by Xray diffraction (XRD) analysis, it has troilite (FeS) structure. Its composition is $\mathrm{Fe}_{1.00 \pm 0.01}: \mathrm{S}_{0.99 \pm 0.02}[16]$.

TRIS-based Schiff base (XC)

Analysis methods

Melting points were obtained on a Mel-Temp II apparatus and are uncorrected. NMR spectra were recorded on a Bruker $500 \mathrm{MHz}$ spectrometer. Chemical shifts are reported in ppm downfield from TMS. Mass spectra were recorded on a Thermo Scientific ISQ LT instrument. Elemental analyses ( $\mathrm{C}, \mathrm{H}, \mathrm{N}, \mathrm{S})$ were conducted using a CE440 Elemental Analyser; the results were found to be in good agreement $( \pm 0.27 \%)$ with the calculated values.

\section{Synthesis}

The reaction sequence for the synthesis of TRIS-based Schiff base $\mathbf{3}$ is described in scheme 1. (TRIS: tris(hydroxymethyl)aminomethane).

4-Butylphenol $(0.15 \mathrm{~g}, 1 \mathrm{mmol})$ and hexamethylenetetramine $(0.28 \mathrm{~g}, 2 \mathrm{mmol})$ were dissolved in trifluoroacetic acid $(20 \mathrm{~mL})$ under nitrogen, and the resulting yellow solution was refluxed for $24 \mathrm{~h}$. The mixture was poured into $4 \mathrm{M} \mathrm{HCl}(100 \mathrm{~mL})$ and stirred for $10 \mathrm{~min}$, after which it 


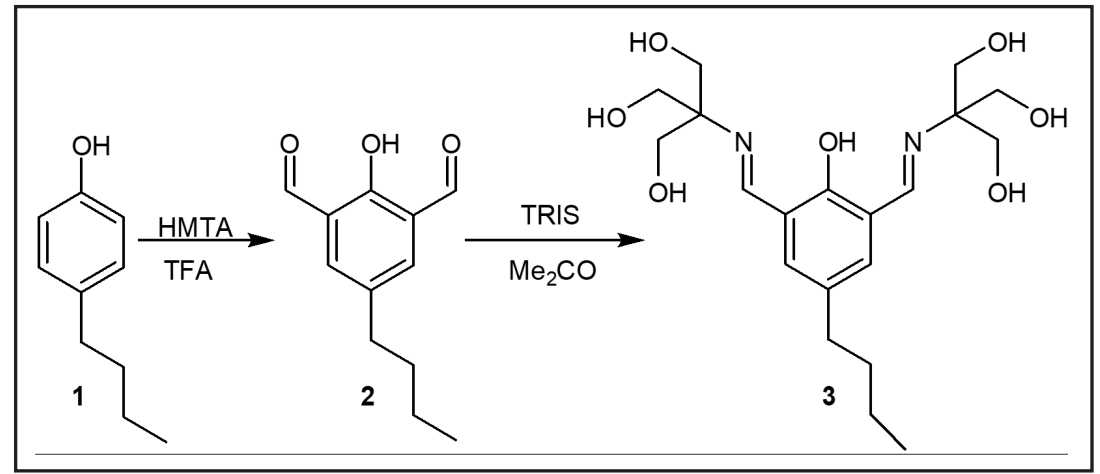

Scheme 1

Synthesis of 4-butyl-2,6-diformylphenol (2)

was extracted with $\mathrm{CH}_{2} \mathrm{Cl}_{2}$. The product was purified by column chromatography using $\mathrm{CH}_{2} \mathrm{Cl}_{2}$ :hexane(1:1) as eluent. This gave compound $\mathbf{2}$ as lightyellow crystals. Yield: $0.35 \mathrm{~g}(65 \%)$.; $\mathrm{mp} 114-115^{\circ} \mathrm{C}$.

${ }^{1} \mathrm{H}$ NMR $\left(C D C l_{3}\right): \delta=0.91\left(3 \mathrm{H}, \mathrm{t}, \mathrm{CH}_{3}\right), 1.30(2 \mathrm{H}, \mathrm{m}$, $\left.\mathrm{CH}_{2}\right), 1.62\left(2 \mathrm{H}, \mathrm{m}, \mathrm{CH}_{2}\right), 2.64\left(2 \mathrm{H}, \mathrm{m}, \mathrm{CH}_{2}\right), 7.89(2 \mathrm{H}, \mathrm{d}$, $\left.\mathrm{H}_{\mathrm{ar}}\right)_{1}, 10.12(2 \mathrm{H}, \mathrm{S}, \mathrm{CHO}), 12.11(1 \mathrm{H}, \mathrm{S}, \mathrm{OH})$;

${ }_{13} \mathrm{C}$ NMR $\left(\mathrm{CDCl}_{3}\right): \delta=13.9,22.5,33.1,35.7,122.9$,

$131.8,137.8,159.7,190.2$

MS (EI): $m / z(\%)=206(M+)$.

\section{Synthesis of TRIS-based Schiff base 3}

To a solution of 4-butyl-2,6-diformylphenol $(2,0.3 \mathrm{~g}, 1.45$ $\mathrm{mmol}$ ) in anhydrous $\mathrm{MeOH}(15 \mathrm{~mL}$ ) tris(hydroxymethyl)aminomethane (TRIS) $(0.35 \mathrm{~g}, 2.9 \mathrm{mmol})$ was added and the resulting solution was heated to reflux for 6 $\mathrm{h}$ under a nitrogen atmosphere to give an orange gummy product on solvent evaporation. The product was purified by crystallization from ethanol. Yield: $0.4 \mathrm{~g}(61 \%)$.; $\mathrm{mp} 181-$ $182^{\circ} \mathrm{C}$.

${ }^{1} \mathrm{H}$ NMR (DMSO- $\left.d_{6}\right): \delta=0.89\left(3 \mathrm{H}, \mathrm{t}, \mathrm{CH}_{3}\right), 1.34(2 \mathrm{H}$, $\left.\mathrm{m}, \mathrm{CH}_{2}\right), 1.60\left(2 \mathrm{H}, \mathrm{m}, \mathrm{CH}_{2}\right), 2.63\left(2 \mathrm{H}, \mathrm{m}, \mathrm{CH}_{2}\right), 3.81(12 \mathrm{H}$, s, $\left.\mathrm{CH}_{2}\right)^{2}, 6.01(6 \mathrm{H}, \mathrm{bs}, \mathrm{OH}), 7.82\left(2 \mathrm{H}, \mathrm{d}, \mathrm{H}_{\mathrm{ar}}\right), 8.84(2 \mathrm{H}, \mathrm{s}$, $\mathrm{CH}), 11.99(\mathrm{H}, \mathrm{S}, \mathrm{OH})$;

${ }^{13} \mathrm{C}$ NMR $\left(\mathrm{CDCl}_{3}\right): \delta=13.8,22.4,33.3,35.5,59.8,62.9$,

$124.1,131.9,158.4,160.5$

MS (EI): $m / z(\%)=412(M+)$.

\section{Electrochemical measurements}

Electrochemical measurements were performed with a Zahner Zennium electrochemical workstation, to which a three electrodes cell was connected. A Pt foil was used as a counter-electrode, and the reference electrode was a saturated calomel electrode (SCE). The working electrode was made of a FeS piece cuts in a parallelepiped shape with the Buehler Isomet equipment. Its exposed surface was $1 \mathrm{~cm}^{2}$. The working electrode was subjected to pretreatments consisting of physical cleaning (polishing with SiC abrasive papers of \#600 and \#1200) and chemical cleaning (ultrasonication for 10 minutes in ethyl alcohol). The volume of air-equilibrated solutions in which the electrochemical experiments were performed was 250 $\mathrm{mL}$. The solutions $\mathrm{pH}$ was 2.26 , temperature was $27^{\circ} \mathrm{C}$, and $X C$ concentration varied between 0 and $0.52 \mathrm{mM}$. The $\mathrm{pH}$ of the solutions was adjusted to 2.26 using a $1 \mathrm{M} \mathrm{HCl}$ solution.

Potentiodynamic polarization measurements were carried out from $-250 \mathrm{mV}$ to $+250 \mathrm{mV}$ versus open circuit potential (OCP) at a rate of $30 \mathrm{mV} / \mathrm{s}$. Cyclic Voltammograms obtained with the FeS electrode immersed in XC solutions were recorded over a potential range of $-1 \mathrm{~V}$ to $1 \mathrm{~V}$ with a scan rate of $100 \mathrm{mV} / \mathrm{s}$.
Surface microscopic analysis

Initial and reacted FeS surface was analyzed by optical microscopy (OM) with a KRUSS optical microscope.

\section{Quantum chemical calculations}

Density functional theory calculations were performed by using the Amsterdam Density Functional package (ADF) $[17,18]$. Calculations use the local density approximation (LDA) in the form of the local exchange-correlation potential of Vosko, Wilk and Nusair (VWN) [19]. Double basis sets (DZ) and the Large frozen core were used for all atoms. The scalar relativistic zeroth order (ZORA) formalism was taken into consideration.

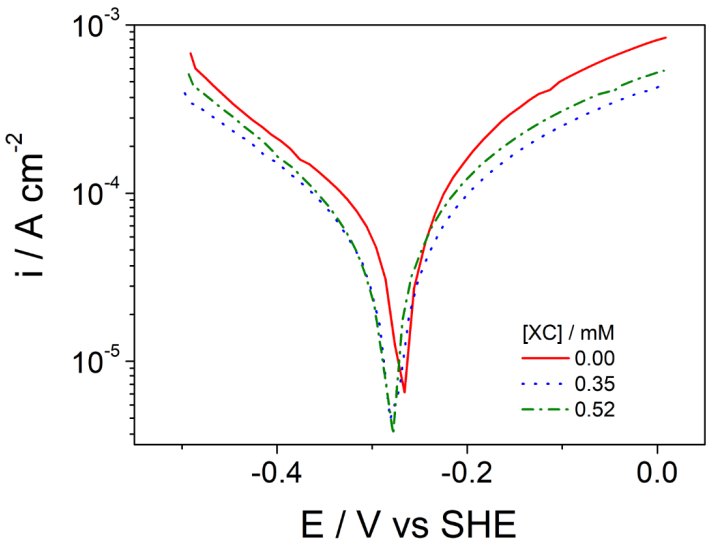

Fig. 1. Potentiodynamic polarization curves of FeS in airequilibrated solutions with different concentrations of $\mathrm{XC}$ at $\mathrm{pH}$ 2.26 and $27^{\circ} \mathrm{C}$. SHE refers to the Standard Hydrogen Electrode

\section{Results and discussions}

Figure 1 shows the potentiodynamic polarization curves of the FeS electrode immersed in XC solutions (0.00-0.52 $\mathrm{mM}$ ).

The electrokinetic parameters were obtained by Tafel analysis and are listed in Table $1 . \mathrm{E}_{\text {corr }}$ is the corrosion potential, $i$ is the corrosion current derrsity, $b$ and $b$ are the anodic and, respectively, cathodic Tafel slopes, and $\eta$ is the inhibition efficiency. The addition of XC to the reaction system produces the decrease of $i$ from $61.2 \mu \mathrm{Acm}^{-2}$ $(0.00 \mathrm{mM})$ to $43 \mu \mathrm{Acm}{ }^{-2}(0.35 \mathrm{mM})$. $\AA^{\text {rrt }}$ further increase of $X C$ concentration to $0.52 \mathrm{mM}$ produces the decrease of $i_{\text {corr }}$ to $34.1 \mu \mathrm{Acm}^{-2}$. The $\mathrm{E}_{\text {cor }}$ does not significantly change when the $X C$ concentration increases, suggesting that the organic compound is a mixed type inhibitor [13].

The inhibitory efficiency $(\eta)$ of the organic molecule was evaluated according to the following relationship:

$$
\eta=\left(1-i_{\text {corr }} / 61.2\right) \cdot 100
$$


Table 1

ELECTROCHEMICAL PARAMETERS AND INHIBITION EFFICIENCY ( $\eta$ ) FOR FeS ELECTRODE IMMERSED IN AQUEOUS SOLUTIONS OF XC WITH CONCENTRATIONS BETWEEN O AND $0.52 \mathrm{mM}$. EXPERIMENTAL CONDITIONS: $p H 2.26$ AND $27^{\circ} \mathrm{C}$

\begin{tabular}{|c|c|c|c|c|c|}
\hline$[\mathrm{XC}]$ & $\mathrm{E}_{\text {corr }} /$ & $\mathrm{i}_{\text {cosr }} /$ & $\mathrm{b}_{\mathrm{a}} /$ & $\mathrm{b}_{\mathrm{c}} /$ & $\eta / \% \%$ \\
$\mathrm{mM}$ & $\mathrm{V}$ & $\mu \mathrm{Acm}-2$ & $\mathrm{mV} / \mathrm{dec}$ & $\mathrm{mV} / \mathrm{dec}$ & \\
\hline 0.00 & -0.284 & 61.2 & 190 & -216 & - \\
\hline 0.35 & -0.286 & 43.0 & 220 & -210 & 29.7 \\
& & & & & \\
\hline 0.52 & -0.283 & 34.1 & 152 & -163 & 44.3 \\
& & & & & \\
\hline
\end{tabular}

where $i_{\text {in }}$ is the corrosion current density of FeS calculated in the presence of XC, and 61.2 is the corrosion current density in the absence of XC. The computed $\eta$ (Table 1) increases with the increase in the concentration of the organic compound.

\section{Cyclic Voltammetry}

Figure 2 shows the cyclic voltammograms obtained for FeS electrode immersed in XC solutions with different concentrations. These curves show that anodic current densities decrease when $\mathrm{XC}$ is added into reaction system. Instead, at extremely negative potentials, XC has a contrary effect on the cathodic current densities. This behavior indicate that at more cathodic potentials the oxygen reduction is replaced with the reduction of polysulfide and elemental sulfur, which have been formed in a lower amount during FeS oxidation in the presence of the inhibitor. At positive potentials Fe(II) is oxidized to Fe(III), and S(-II) to $\mathrm{S}(0)$ and $\mathrm{S}(+\mathrm{VI})$ [20-26].

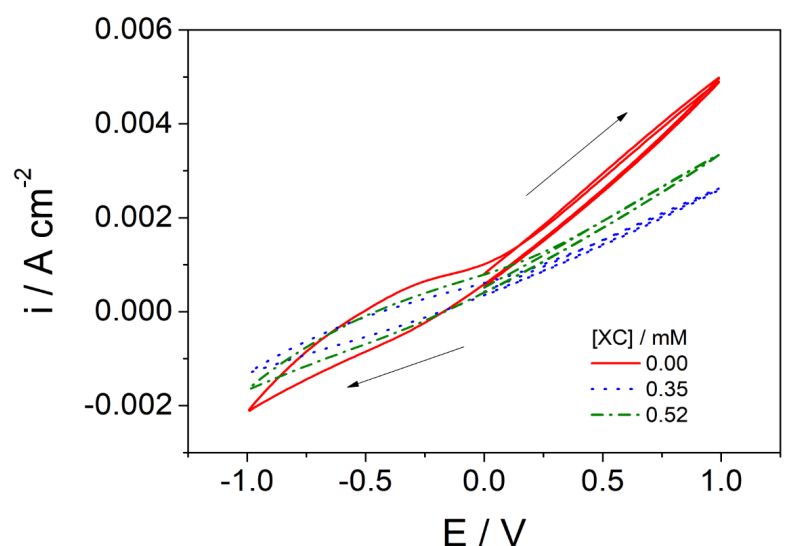

Fig. 2. Cyclic Voltamograms obtained for FeS electrode in XC solutions at $\mathrm{pH} 2.26$ and temperature of $27^{\circ} \mathrm{C}$

\section{Optical microscopy analysis}

The inspection of the FeS surface was performed under optical microscope. The obtained images are shown in Figure 3. From these images, we can observe that the grinding traces present on the initial surface (Figure 3a) disappear during electrode polarization in the experimental solutions (Figures 3b-d). Anyway, from the collected images is difficult to see relevant differences between the FeS corroded in the three experimental solutions.
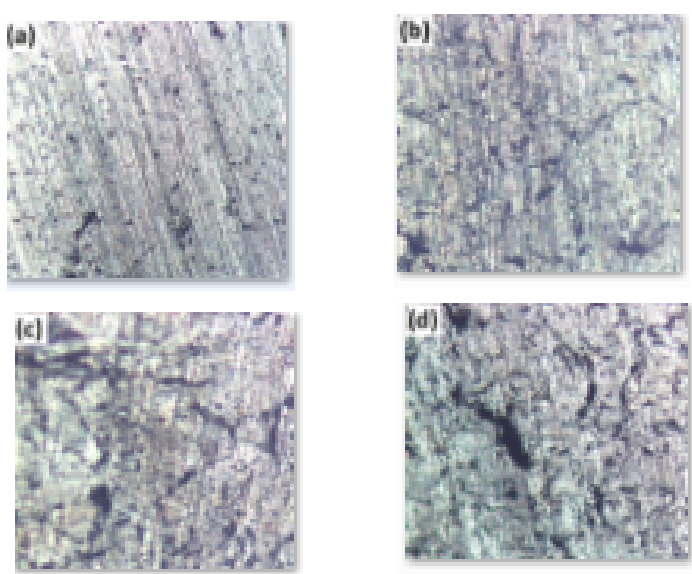

Fig. 3. The initial FeS surface (a) and FeS surface after potentiodynamic polarization in XC solutions of $0.00 \mathrm{mM}(\mathrm{b}), 0.35$ $\mathrm{mM}$ (c) and $0.52 \mathrm{mM}$ (d) (magnification 100x)

\section{Quantum chemical calculations}

The electronic properties of XC were analyzed by quantum chemical method. The quantum chemical parameters: frontier molecular orbitals energies $\left(\mathrm{E}_{\text {Hom }}\right.$ and $\left.\mathrm{E}_{\text {(umo }}\right)$, energy gap $(\Delta \mathrm{E})$ and dipole have been derived from the theoretical analysis. The calculated $\mathrm{E}_{\text {номо }}, \mathrm{E}_{\text {Luм }}, \Delta \mathrm{E}$ and dipole values for XC are presented in Table 2 . One is thought that a higher $\mathrm{E}_{\text {номо }}$ value is related with high electron donating capacity of inhibitor, whereas a lower $E_{14 m}$ value is correlated to strong electronic interactions between inhibitor and solid surface, therefore low ÄE values are associated with high electron donating capacity of inhibitor and a high $\eta$ [27-28]. Figure 4 shows the HOMO and LUMO electron distributions of XC molecule. The HOMO of $X C$ is distributed around one of the two moieties containing nitrogen, while the LUMO is especially distributed around the aromatic moiety. Although $\Delta \mathrm{E}$ indicates a high $\eta$, nevertheless the determined values are moderate. Perhaps the best explanation of this discrepancy resides in the relatively low extension of the two frontier

\begin{tabular}{|c|c|}
\hline Eluso (Hatree) & -0.114 \\
\hline EHowo (Hatree) & -0.194 \\
& \\
\hline$\Delta \mathrm{E}$ (Hatree) & 0.08 \\
& \\
\hline Dipole (Bohr) & 4.618 \\
& \\
\hline
\end{tabular}

Table 2

CALCULATED QUANTUMCHEMICAL PROPERTIES FOR XC

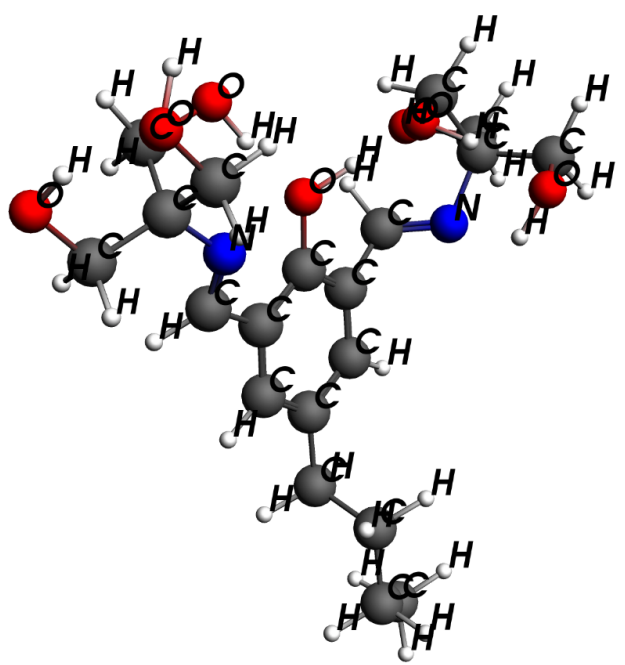




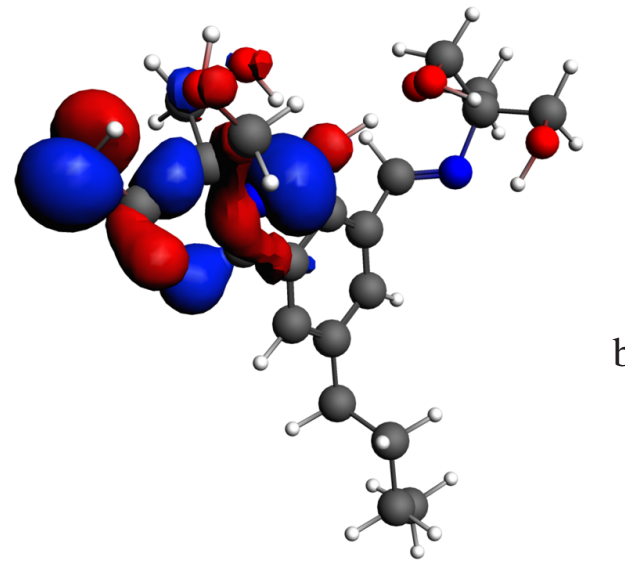

b

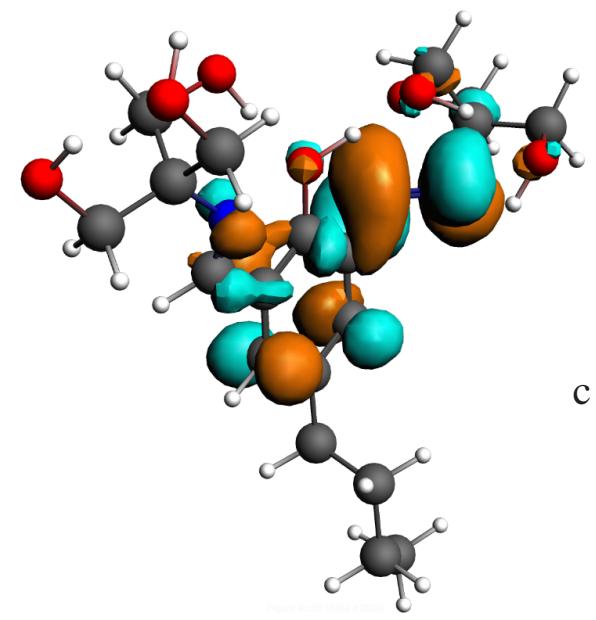

Fig. 4. Optimized structure of XC (a), and distribution of HOMO (b) and LUMO (c) frontiers orbitals in XC

molecular orbitals and possible steric hindrances, which block the effective XC adsorption. Therefore, molecules with greater inhibitory efficiencies should have a more extended distribution of the frontier molecular orbitals, and the branched and voluminous structures replaced with heavy and less voluminous moieties.

\section{Conclusions}

The effect of XC on the oxidative dissolution of FeS at $p H$ 2.26 and $27^{\circ} \mathrm{C}$ was investigated by Potentiodynamic polarization, Cyclic Voltammetry, Optical Microscopy and quantum chemical calculations. The XC concentration varied between 0 and $0.52 \mathrm{mM}$. It was observed that XC decreases the corrosion current densities associated to the oxidative dissolution of FeS. Our computations indicate that the inhibitory effect of XC is due to its adsorption on the troilite surface.

\section{References}

1. CANFIELD, D.E., RAISWELL, R., Pyrite formation and fossil preservation. In Taphonomy: Releasing the Data Locked in the Fossil Record. (P.A. Allison and D.E.G. Briggs eds.) Plenum Press, New York, 1991, p. 337-387.
2. CAI, M.F., DANG, Z., CHEN, Y.W., BELZILE, N., Chemosphere 6, 2005, p. 659-667.

3. JANZEN, M.P., NICHOLSON, R.V., SCHARER, J.M., Geochim. Cosmochim. Acta 64, 2000, p. 1511-1522.

4. DUINEA, M.I., SANDU, A.M., PETCU, M.A., DABULEANU, I., CARAC, G., CHIRITA, P, J. Electroanal. Chem. 804, 2017, p. 165-170.

5. WOLTHERS, M., CHARLET, L., VAN DER WEIJDEN, C.H., VAN DER LINDE, P.R., RICKARD, D., Geochim. Cosmochim. Acta 69, 2005, p. 3483-3492.

6. WIDLER, A.M., SEWARD, T.M., Geochim. Cosmochim. Acta 66, 2002, p. 383-402.

7. CHIRITA, P., BERDAN, I., Rev. Chim. (Bucharest), 56, no.5, 2005, p. 477-481.

8. CHIRITA, P., Min. Process. Extractive Metall. Rev. 37, 2016, p. 305310.

9. THOMAS, J.E., SKINNER, W.M., SMART, R.ST.C., Geochim. Cosmochim. Acta 67, 2003, p. 831-843.

10. MIKHLIN, Y.L., KUKLINSKIY, A.V., PAVLENKO, N.I., VARNEK, V.A., ASANOV, I.P., OKOTRUB, A.V., SELYUTIN, G.E., SOLOVYEV, L.A., Geochim. Cosmochim. Acta 66, 2002, p. 4057-4067.

11. PRATT, A.R., NESBITT, H.W., Am. J. Sci. 297, 1997, p. 807-820.

12. BELZILE, N., CHEN, Y.W., CAI, M.F., LI, Y., J. Geochem. Explor. 84, 2004, p. 65-76.

13. DUINEA, M.I., COSTAS, A., BAIBARAC, M., CHIRITA, P., J. Colloid. Interface Sci., 467, 2016, p. 51-59.

14. CHIRITA, P., BADICA, C.E., CONSTANTIN, C.A., BIRSA, M.L., MATEI, E., BAIBARAC, M., Surf. Interface Anal. 46, 2014, p. 842-846.

15. BADICA, C.E., CHIRITA, P., Electrochim. Acta 178, 2015, p. 786-796. 16. CHIRITA, P., SCHLEGEL, M.L., Int. J. Miner. Process. 135, 2015, p. 57-64.

17. BAND2016, SCM, Theoretical Chemistry, Vrije Universiteit, Amsterdam, The Netherlands, http://www.scm.com. Authors and contributors: P.H.T. Philipsen, G. te Velde, E.J . Baerends, J.A. Berger, P.L. de Boeij, M. Franchini, J.A. Groeneveld, E.S. Kadantsev, R. Klooster, F. Kootstra, P. Romaniello, M. Raupach, D.G. Skachkov, J.G. Snijders, C.J .O. Verzijl, J.A. Celis Gil, J. M. Thijssen, G. Wiesenekker, T. Ziegler. 18. TE VELDE, G., BAERENDS, E.J., Phys. Rev. B 44, 1991, p. 7888-7903. 19. VOSKO, S.H., WILK, L., NUSAIR, M., Can. J. Phys. 58, 1980, p. 12001211.

20. CRUZ R., GONZALEZ I., MONROY M., Appl. Geochem. 20, 2005, p. 109-121.

21. CHIRITA, P., Chem. Biochem. Eng. Q. 21, 2007, p. 257-264.

22. GHAHREMANINEZHAD, A., ASSELIN, E., DIXON, D.G., J. Electrochem. Soc. 157, 2010, p. C248-C257.

23. CAMENITA, I., MORARU, M., SCHIOPESCU, A.,Rev. Chim.(Bucharest) 61, no.7, 2010, p. 665-668.

24. GARBALAU, N., ROMAN, E., REV. CHIM. (Bucharest) 54, no.6, 2003, p. 538-539.

25. VASILE G.G., ARNOLD G.L., BUICA G.O., E. DIACU, E.M. UNGUREANU, C. DINU, REV.CHIM. (Bucharest) 69. no.1, 2018, p. 2126.

26. FITOZ, A., NAZIR, H., OZGUR, M., EMREGUL, E., EMREGUL, K.C., Corros. Sci. 133, 2018, p. 451-464.

27. HU, K., ZHUANG, J., DING, J., MA, Z., WANG, F., ZENG, X., Corros. Sci. 125, 2017, p. 68-76.

28. BEDAIR, M.A., EL-SABBAH, M.M.B., FOUDA, A.S., ELARYIAN, H.M., Corros. Sci. 128, 2017, p. 54-72.

$\overline{\text { Manuscript received: } 18.05 .2019}$ 